\title{
Inclination towards a research career among first year medical students: an international study
}

\author{
Say-Beng Tan ${ }^{1,2,3}$, Gerald CH Koh ${ }^{4}$, Ying-Wei Ding ${ }^{1,3}$, Rahul Malhotra ${ }^{1}$, Tam Cam Ha ${ }^{1,3}$, \\ Ricardo Pietrobon ${ }^{1,5}$, Rina Kusumaratna ${ }^{6}$, Rodney Nan Tie ${ }^{7}$, Guilherme Cunha ${ }^{8}$, \\ Henrique Martins ${ }^{9}$, Arnfinn Seim ${ }^{10}$, Fernando Altermatt ${ }^{11}$, Aya Biderman ${ }^{12}$, \\ Thandi Puoane ${ }^{13}$, Elias Carvalho ${ }^{14}$, Truls Ostbye ${ }^{1,5}$
}

\begin{abstract}
Introduction: The importance of fostering clinicians who are also scientists is well recognized. It is of value to assess medical students' inclination towards and self-perceived readiness for a research career, as this has implications on the future development of such individuals.

Methods: A questionnaire was self-administered to all consenting first year medical students from eleven universities in ten countries. Questions were asked pertaining to inclination towards research careers, confidence in research methodology and ability to understand medical literature.

Results: A total of 1354 questionnaires were completed, with a mean response rate of $76.5 \%$. While $24.8 \%$ students expressed an interest in pursuing a research career, $48.3 \%$ were undecided. Students with prior research experience and students who were attending graduate medical school programmes were more likely to have an interest in a research career after graduation. Males were more interested in learning about biostatistics than females, while the reverse was true for learning about research ethics.

Discussion: Most students in their first year of medical school are not inclined towards a research career. This finding applies internationally, across different countries and medical school systems. Thus, the onus is on medical schools to help transform the perception and attitudes of their students during the course of their training, so that a greater proportion will be interested in and ultimately pursue research careers.
\end{abstract}

Keywords: medical student, attitudes, research, biomedical, career choice, surveys

\section{Introduction}

The lack of physicians leading and being involved in research projects can be a barrier to the progress of biomedical research. The

\footnotetext{
${ }^{1}$ Duke-NUS Graduate Medical School, Singapore

Singapore Clinical Research Institute, Singapore

${ }^{3}$ National Cancer Centre Singapore, Singapore

${ }^{4}$ Department of Epidemiology and Public Health, Yong Loo Lin

School of Medicine, National University of Singapore, National

University Health System, Singapore

${ }^{5}$ Duke University Medical Centre, Durham, NC, USA

${ }^{6}$ Trisakti University, Jakarta, Indonesia

${ }^{7}$ Tropical Medical Training, North Queensland, Australia

${ }^{8}$ Federal University of Minas Gerais, Belo Horizonte, Brazil

${ }^{9}$ Faculdade de Ciencias da Saúde, Universidade da Beira Interior, Portugal

${ }^{10}$ Norwegian University of Science and Technology (NTNU), Norway

${ }^{11}$ Pontificia Universidad Catolica de Chile, Santiago, Chile

${ }^{12}$ Ben-Gurion University, Beer-Sheva, Israel

${ }^{13}$ University of the Western Cape, South Africa

${ }^{14}$ Universidade Estadual De Maringa, Maringa, Brazil

Corresponding author:

Say-Beng TAN

Duke-NUS Graduate Medical School,

Centre for Quantitative Medicine

8 College Road, Level 4, Singapore 169857,

Tel:+65 6601 1095,Fax:+65 62227453 ,

Email: gmstsb@nus.edu.sg
}

growing number of PhD full time researchers has been driven by the increasing technical knowledge necessary in many fields. However, to remain clinically relevant, it is of critical importance, for biomedical research more broadly, and clinical research in particular, to maintain direct connection with patients and the clinical milieu. This lack and declining numbers of physicians in clinical research, at least in a number of countries (Ley and Rosenberg, 2005, Rosenberg, 1999), has led to the increasing emphasis in these and other countries on training 'physician scientists' or 'clinician scientists' (defined as medical graduates who pursue a career primarily in biomedical research) and 'clinician investigators' (medical graduates whose primary role is patient care, while also engaging in some research activity). In particular, various initiatives have been launched to develop such expertise, for example by the National Institutes of Health and other organisations in the United States (Ley and Rosenberg, 2005), by the National Medical Research Council in 
Singapore and by the National Commission for Scientific and Technological Research in Chile. However, while a key factor in the decision to pursue a career in research is dependent upon the individual's experience in medical school (Davis \& Kelley, 1982), there is evidence that the number of medical students who intend to pursue research careers is declining (Neilson, 2003).

Various studies have been conducted to investigate the career choices of medical students (Al-Nuaimi et al., 2008, Burazeri et al., 2005, Huda and Yousuf, 2006, Koenig, 1992) and more specifically, the factors that influence the choice to pursue a career in research (Kassebaum et al., 1995). Among the key findings are that students who participated in research projects/electives and authored research papers while in medical school were more likely to take up research careers (Houlden et al., 2004, McManus et al., 1999, Nguyen-Van-Tam et al., 2001, Solomon et al., 2003). As might be expected, students who pursued a graduate research degree along with a medical degree, e.g. an MD/PhD, were more likely to pursue research careers (Andriole et al., 2008). Also, research training and experience while at medical school influenced both future career developement as well as research performance (Evered et al., 1987). The strong influence of completing a graduate research degree along with a medical degree in the choice of a career in research was also found in a comprehensive systematic review of career choices of medical students (Straus et al., 2006).

The overall objective of this study was to investigate students from different medical schools around the world as to their inclination towards, interest in, and perceived readiness for a research career. It was also of interest to assess the background and research knowledge of students when they first entered different medical schools, each with their own criteria for admission and system of teaching and training. Specifically, we were interested in: 1) assessing first year medical school students in their confidence in biomedical research methodology and the ability to interpret and understand biomedical literature and 2) describing their background and inclination towards research at the point of entry into medical school. We also wanted to explore differences in these specific domains between male and female students, and between students who reported having and not having conducted any research prior to medical school.

\section{Methods}

Medical schools from eleven universities in ten countries across five continents took part in this study through an international collegial network of medical school faculty members from different parts of the world, with very different educational and health care systems. The study team sought to include a variety of schools to provide as good a representation of medical students worldwide.

A self-administered, non-anonymous questionnaire was used to survey all first year medical students (who consented) at each of the collaborating schools. This was done before the students were exposed to any substantial teaching on research methods as part of their medical school programme. The questionnaire, in English, was developed by the authors after extensive, iterative discussions in person, via telephone and email. The questionnaire was pilot-tested on three medical students from one of the medical schools (Yong Loo Lin School of Medicine, Singapore) and refined based on their suggestions. It included questions on age, gender, highest qualification obtained prior to medical school, previous research experience (courses taken on research or research ethics, research conducted), peer-reviewed publication history, whether the quality of the research produced by a medical school influenced their choice of medical school, frequency of regular biomedical journal reading, inclination towards research during medical school and after graduation, main motivation for being inclined or disinclined, interest in pursuing biomedical research oriented Masters and PhD after graduation, role models for interest in research and percentage of time they envisioned spending on research after establishing their career as physicians. Their confidence, perceived ability and perceived learning need in the domains of research ethics, study design and biostatistics were also assessed.

The questionnaire was translated into Portuguese (in Portugal and Brazil; the versions in the two countries were essentially the same except for minor modifications to comply with spelling differences), into Spanish (in Chile) and into Hebrew (in Israel). The responsibility for translation was taken by the site investigator in each country along with (in the case of Portuguese) one other coinvestigator proficient in the language. In all the other countries the questionnaire was administered in English. 
In addition, a 'site questionnaire', gathering background information on the particular medical school, including its teaching philosophy, curriculum and profile of the students enrolled, was completed by each site investigator.

\section{Study implementation}

Each site investigator was sent a soft-copy of the questionnaire along with a system for assigning a unique identification number to each questionnaire. Each site was responsible for ensuring that the study obtained the necessary Institutional Review Board/Ethics Committee approval as required by the regulations of the country and institution.

The exact procedure for administering the questionnaires varied somewhat depending on the set up and structure within each site. The typical approach involved the investigator seeking permission from colleagues involved in coordinating or conducting lectures to allow the students to be surveyed at an appropriate time-point. For example, in one of the medical schools, the questionnaire was completed during a session related to research/evidence based medicine and was used as a teaching tool and basis for class discussion (after the questionnaires had been completed). The informed consent process, and in particular the need for written informed consent, varied from institution to institution, but in all cases, complied with the policy of the particular medical school and country. Participation was entirely voluntary and those who did not wish to participate were free to decline. No financial or other incentives were provided. The students completed their questionnaires individually. Site investigators then sent the de-identified data to the study team in Singapore, either as hardcopies for data entry, or as softcopies after data entry into a standard excel template prepared by the study team. In one university (Federal University of Minas Gerais in Brazil) an electronic data capture system was used with students entering their responses directly into the system.

\section{Statistical Analysis}

Descriptive summary statistics were computed for all the universities combined, as well as for individual universities. Association of gender (male/female) and of research experience prior to medical school (yes /no) with influence of the quality of the research produced by a medical school, the choice of the medical school, inclination towards research during medical school and after graduation, interest in pursuing biomedical research oriented Masters and $\mathrm{PhD}$ after graduation, percentage of time they envisioned spending on research after establishing their career as physicians, and perceived learning need in the domains of research ethics and biostatistics was explored using Chi-square tests. Statistical analysis was carried out using SPSS Version 15.0 (SPSS Inc, Chicago USA, 2006). Participants with missing values for some of the questionnaire items were included in the analysis with no imputation procedure carried out.

\section{Results}

A total of 1354 first year medical students from 11 universities in 10 countries spanning five continents agreed to participate in the study (Table 1). The first medical school administered the survey in October 2008, the last in November 2009. The mean response rate was $76.5 \%$ (range: $26.0 \%$ to $100.0 \%$ ). The lowest response rate of $26 \%$ was from a site where, at the time of the survey, students were busy preparing for their examinations.

Table 1 summarises the characteristics of each participating university and the students who took part in the study. Only two of the medical schools accepted students who already had a first degree (i.e. they were graduate programmes); the others accepted mostly undergraduates. The schools used different teaching methods and most provided research opportunities both within and outside the medical school curriculum. Of the 1354 students, $55.9 \%$ were female, the median age being 19 years (range: 16 to 49 ), $83.8 \%$ had never previously taken a course in research, $94.2 \%$ had never previously taken a course in research ethics and $69.7 \%$ had no previous research experience.

In terms of research interest and inclination, $24.8 \%$ of the students expressed interest in pursuing a career in research after graduation, while $48.3 \%$ were undecided (Table 2). Among those who did not already possess a research oriented Masters or PhD qualification, 34.5\% indicated that they were keen to pursue such a programme after graduation from medical school while $47.3 \%$ were undecided. Also $74.5 \%$ indicated that the particular medical school's reputation for quality of research was an important factor in determining their choice of medical school. The two schools with graduate medical programmes had, not surprisingly, a higher proportion of students with previous experience of research and research training. This appeared to translate into greater inclination towards research careers ( $P=0.004$, results not shown in Tables). However, neither had the highest proportion of students who felt that the quality of research was important in their choice of medical school, which was the highest in Trisakti University. 
Table 1: Profile of the medical schools included in the study, and demographic profile and previous research experience of study participants

\begin{tabular}{|c|c|c|c|c|c|c|c|c|c|c|c|c|}
\hline \multirow{2}{*}{ Variable } & \multicolumn{11}{|c|}{ University } & \multirow{2}{*}{ Overall } \\
\hline & NUS & Duke & PUC & BGU & UEM & UFMG & NTNU & TU & FCSU & $\mathrm{JCU}$ & UCT & \\
\hline \multicolumn{13}{|l|}{ Medical school profile } \\
\hline Country & Singapore & USA & Chile & Israel & Brazil & Brazil & Norway & Indonesia & Portugal & Australia & South-Africa & \\
\hline Students surveyed & 281 & 82 & 98 & 41 & 24 & 129 & 108 & 280 & 118 & 167 & 26 & 1354 \\
\hline Total Intake & 316 & 100 & 120 & 73 & 40 & 320 & 120 & 280 & 120 & 180 & 100 & 1769 \\
\hline Response rate (\%) & 88.9 & 82.0 & 81.7 & 56.2 & 60.0 & 40.3 & 90.0 & 100.0 & 98.3 & 92.8 & 26.0 & 76.5 \\
\hline Admission criteria & G\&UG & G & UG & UG & UG & UG & UG & UG & UG & UG & UG & \\
\hline $\begin{array}{l}\text { Duration of programme } \\
\text { (Years) }\end{array}$ & $\begin{array}{l}4(\mathrm{G}) \\
5(\mathrm{UG})\end{array}$ & 4 & 6 & 6 & 6 & 6 & 6 & 4 & 6 & 6 & 6 & \\
\hline $\begin{array}{l}\text { Year first taught } \\
\text { Biostatistics or Research } \\
\text { Design }\end{array}$ & $\begin{array}{l}\text { Year } 1(\mathrm{G}) \\
\text { Year } 3(\mathrm{UG})\end{array}$ & Year 3 & Year 1 & Year 1 & Year 1 & Year 2 & Year 2 & Year $1 \& 2$ & Year 1 & Year 1 & Year 1 & \\
\hline Teaching methodology & $\begin{array}{l}\mathrm{TBL}(\mathrm{G}) \\
\mathrm{LT}(\mathrm{UG})\end{array}$ & LT & PBL & LT & TBL & LT & PBL & Mix & PBL & Mix & LT & \\
\hline $\begin{array}{l}\text { Research opportunities } \\
\text { offered within or outside } \\
\text { school curriculum }\end{array}$ & Both & Both & Both & Within only & Outside only & Both & Both & Outside only & Both & Both & Both & \\
\hline Study participant profile & $\begin{array}{l}\mathrm{N}=\mathbf{2 8 1} 1^{*} \\
\mathrm{n}(\%)\end{array}$ & $\begin{array}{l}\mathrm{N}=82^{\star} \\
\mathrm{n}(\%)\end{array}$ & $\begin{array}{l}\mathrm{N}=98^{*} \\
\mathrm{n}(\%)\end{array}$ & $\begin{array}{l}\mathrm{N}=41^{*} \\
\mathrm{n}(\%)\end{array}$ & $\begin{array}{l}\mathrm{N}=24^{*} \\
\mathrm{n}(\%)\end{array}$ & $\begin{array}{l}\mathrm{N}=129^{*} \\
\mathrm{n}(\%)\end{array}$ & $\begin{array}{c}\mathrm{N}=108^{*} \\
\mathrm{n}(\%)\end{array}$ & $\begin{array}{l}\mathrm{N}=280^{*} \\
\mathrm{n}(\%)\end{array}$ & $\begin{array}{l}\mathrm{N}=118^{*} \\
\mathrm{n}(\%)\end{array}$ & $\begin{array}{l}\mathrm{N}=167^{*} \\
\mathrm{n}(\%)\end{array}$ & $\begin{array}{l}\mathrm{N}=26^{*} \\
\mathrm{n}(\%)\end{array}$ & $\begin{array}{l}\mathrm{N}=1354^{*} \\
\mathrm{n}(\%)\end{array}$ \\
\hline \multicolumn{13}{|l|}{ Gender } \\
\hline - Male & $142(50.5)$ & $45(54.9)$ & $53(54.1)$ & $23(56.1)$ & $12(50.0)$ & $67(51.9)$ & $36(33.3)$ & $94(33.6)$ & $44(37.3)$ & $69(41.3)$ & $12(46.2)$ & $597(44.1)$ \\
\hline - Female & $139(49.5)$ & $37(45.1)$ & $45(45.9)$ & $18(43.9)$ & $12(50.0)$ & $62(48.1)$ & $72(66.7)$ & $186(66.4)$ & $74(62.7)$ & $98(58.7)$ & $14(53.8)$ & $757(55.9)$ \\
\hline Median age in years & 19 & 23 & 18 & 24 & 19 & 20 & 21 & 18 & 18 & 18 & 19 & 19.0 \\
\hline (Min, Max) & $(18,30)$ & $(22,33)$ & $(17,25)$ & $(19,27)$ & $(18,25)$ & $(17,35)$ & $(19,31)$ & $(16,23)$ & $(17,32)$ & $(16,49)$ & $(16,24)$ & $(16,49)$ \\
\hline \multicolumn{13}{|l|}{$\begin{array}{l}\text { Highest academic } \\
\text { qualification obtained }\end{array}$} \\
\hline - No previous degree & $210 / 280(75)$ & $0(0.0)$ & $87(88.8)$ & $36 / 40(90.0)$ & $23(95.8)$ & $120(93.0)$ & 80/103 (77.7) & 274/279 (98.2) & 101/111 (91.0) & 147/166 (88.6) & $24(92.3)$ & $1102 / 1338(82.4)$ \\
\hline - Diploma & $17 / 280(6.1)$ & $0(0.0)$ & $0(0.0)$ & $1 / 40(2.5)$ & $0(0.0)$ & $1(0.8)$ & $12 / 103(11.7)$ & $5 / 279(1.8)$ & $0(0.0)$ & $8 / 166(4.8)$ & $0(0.0)$ & $44 / 1338(3.3)$ \\
\hline - Bachelors & $44 / 280(15.7)$ & $74(90.2)$ & $11(11.2)$ & $3 / 40(7.5)$ & $1(4.2)$ & $7(5.4)$ & $11 / 103(10.7)$ & $0(0.0)$ & 9/111 (8.1) & 8/166 (4.8) & $2(7.7)$ & $170 / 1338(12.7)$ \\
\hline - Masters & $8 / 280(2.9)$ & $7(8.5)$ & $0(0.0)$ & $0(0.0)$ & $0(0.0)$ & $1(0.8)$ & $0(0.0)$ & $0(0.0)$ & $1 / 111(0.9)$ & $3 / 166(1.8)$ & $0(0.0)$ & 20/1338 (1.5) \\
\hline - PhD and above & $1 / 280(0.4)$ & $1(1.2)$ & $0(0.0)$ & $0(0.0)$ & $0(0.0)$ & $0(0.0)$ & $0(0.0)$ & $0(0.0)$ & $0(0.0)$ & $0(0.0)$ & $0(0.0)$ & $2 / 1338(0.1)$ \\
\hline $\begin{array}{l}\text { Have taken a course in } \\
\text { research }\end{array}$ & $95(33.8)$ & $48(58.5)$ & $5(5.1)$ & $4(9.8)$ & $0(0.0)$ & $1(0.8)$ & $13(12.0)$ & $37 / 279(13.3)$ & 3/107 (2.8) & 9/167 (5.4) & $2 / 26(7.7)$ & $217 / 1342(16.2)$ \\
\hline $\begin{array}{l}\text { Have taken a course in } \\
\text { research ethics }\end{array}$ & $38(13.5)$ & $18(22.0)$ & $0(0.0)$ & $1 / 40(2.5)$ & $0(0.0)$ & $0(0.0)$ & $7(6.5)$ & $7 / 277(2.5)$ & 2/107 (1.9) & $5 / 166(3.0)$ & $0(0.0)$ & 78/1338 (5.8) \\
\hline $\begin{array}{l}\text { Have some prior } \\
\text { research experience }\end{array}$ & $154 / 279(55.2)$ & $78(95.1)$ & $2 / 97(2.1)$ & $0(0.0)$ & $1(4.2)$ & $5(3.9)$ & $9(8.3)$ & $132 / 275(48.0)$ & $8(7.4)$ & $12(7.2)$ & $4(15.4)$ & 405/1336 (30.3) \\
\hline
\end{tabular}

NUS = National University of Singapore (includes students from both Yong Loo Lin School of Medicine and from Duke-NUS Graduate Medical School), Duke $=$ Duke University, PUC $=$ Pontificia Universidad Catolica de Chile, BGU = Ben-Gurion University, UEM = Universidade Estadual De Maringa, UFMG = Federal University of Minas Gerais, NTNU = Norwegian University of Science and Technology, TU = Trisakti University, FCSU = Faculdade de Ciencias da Saúde, Universidade da Beira Interior, JCU = James Cook University, UCT = University of Cape Town, G = Graduate, UG = Undergraduate, TBL = Predominantly Team-based learning, LT = Predominantly Lecture and tutorials, PBL = Predominantly Problem-based learning, Mix: Mix of the three teaching methodologies (TBL, LT, PBL)

* In cells where denominators are not included, all responders answered the question 
Table 2: Research interest, and research inclination after graduation of study participants

\begin{tabular}{|c|c|c|c|c|c|c|c|c|c|c|c|c|}
\hline \multirow[b]{2}{*}{ Variable } & \multicolumn{11}{|c|}{ University } & \multirow[b]{2}{*}{$\begin{array}{l}\text { Overall } \\
\mathrm{n}(\%)\end{array}$} \\
\hline & $\begin{array}{c}\text { NUS } \\
\mathrm{N}=281^{*} \\
\mathrm{n}(\%)\end{array}$ & $\begin{array}{c}\text { Duke } \\
\mathrm{N}=82^{*} \\
\mathrm{n}(\%)\end{array}$ & $\begin{array}{c}\text { PUC } \\
\mathrm{N}=98^{*} \\
\mathrm{n}(\%)\end{array}$ & $\begin{array}{l}\text { BGU } \\
\mathrm{N}=41^{*} \\
\mathrm{n}(\%)\end{array}$ & $\begin{array}{c}\text { UEM } \\
\mathrm{N}=24^{*} \\
\mathrm{n}(\%)\end{array}$ & $\begin{array}{l}\text { UFMG } \\
\mathrm{N}=129^{\star} \\
\mathrm{n}(\%)\end{array}$ & $\begin{array}{l}\text { NTNU } \\
\mathrm{N}=108^{\star} \\
\mathrm{n}(\%)\end{array}$ & $\begin{array}{c}\text { TU } \\
\mathrm{N}=280^{*} \\
\mathrm{n}(\%)\end{array}$ & $\begin{array}{c}\text { FCSU } \\
\mathrm{N}=118^{*} \\
\mathrm{n}(\%)\end{array}$ & $\begin{array}{c}\text { JCU } \\
\mathrm{N}=167^{*} \\
\mathrm{n}(\%)\end{array}$ & $\begin{array}{c}\text { UCT } \\
\mathrm{N}=26^{*} \\
\mathrm{n}(\%)\end{array}$ & \\
\hline \multicolumn{13}{|l|}{$\begin{array}{l}\text { Importance of the quality } \\
\text { of research in choice of } \\
\text { medical school }\end{array}$} \\
\hline - Important & $169 / 278(60.8)$ & $71(86.6)$ & 75 (76.5) & $19 / 40(47.5)$ & $21(87.5)$ & $113(87.6)$ & $47 / 106$ (44.3) & 259/267 (97.0) & 83/105 (79.0) & 103/164 (62.8) & $23(88.5)$ & 983/1319 (74.5) \\
\hline $\begin{array}{l}\text { Students who read } \\
\text { biomedical journals } \\
\text { regularly }\end{array}$ & $48 / 280(17.1)$ & $22(26.8)$ & $6 / 97(6.2)$ & $6 / 40(15.0)$ & $5 / 23(21.7)$ & $32(24.8)$ & $36(33.3)$ & $63 / 276(22.8)$ & $35 / 106(33.0)$ & $25 / 167$ (15.0) & $7 / 25(28.0)$ & 285/1333 (21.4) \\
\hline \multicolumn{13}{|l|}{$\begin{array}{l}\text { Interest in biomedical } \\
\text { research career after } \\
\text { graduation? }\end{array}$} \\
\hline - Yes & $59 / 279(19.0)$ & $25 / 81(30.9)$ & $22(22.4)$ & $12 / 40(30.0)$ & 8/19 (42.1) & $30(23.3)$ & $22(20.4)$ & $91(32.5)$ & 22/102 (21.6) & $35(21.0)$ & $3(11.5)$ & $329 / 1329(24.8)$ \\
\hline - Undecided & $123 / 279(44.1)$ & $39 / 81(48.1)$ & $62(63.3)$ & $23 / 40(57.5)$ & $8 / 19(42.1)$ & $68(52.7)$ & $56(51.9)$ & $127(45.4)$ & 47/102 (46.1) & $75(44.9)$ & $14(53.8)$ & $642 / 1329(48.3)$ \\
\hline $\begin{array}{l}\text { Students who have a role } \\
\text { model who inspired them } \\
\text { to take up a biomedical } \\
\text { research career? }\end{array}$ & $37 / 277(13.4)$ & $28 / 79(35.4)$ & $14 / 96(14.6)$ & $7 / 40$ (17.5) & $4(16.7)$ & $14(10.9)$ & 12/106 (11.3) & $36 / 272(13.2)$ & $10 / 100(10.0)$ & 29/164 (17.7) & $6(23.1)$ & 197/1313 (15.0) \\
\hline $\begin{array}{l}\text { Students interest in } \\
\text { research project outside } \\
\text { official medical school } \\
\text { curriculum }\end{array}$ & $140(49.8)$ & $48 / 81(59.3)$ & 70/95 (73.7) & $35(85.4)$ & 22/23 (95.7) & $91 / 126(72.2)$ & $38(35.2)$ & 159/268 (59.3) & 69/97 (71.1) & 69/165 (41.8) & $15 / 23(65.2)$ & 756/1308 (57.8) \\
\hline \multicolumn{13}{|l|}{$\begin{array}{l}\text { Interest to pursue } \\
\text { research oriented Masters } \\
\text { or PhD after graduation }\end{array}$} \\
\hline - Yes & $37 / 276$ (13.4) & $8 / 73(11.0)$ & 26/97 (26.8) & $8(19.5)$ & $11(45.8)$ & $81(62.8)$ & $41(38.0)$ & 130/271 (48.0) & $61 / 68(89.7)$ & $30(18.0)$ & $8 / 24(33.3)$ & $441 / 1278$ (34.5) \\
\hline - Undecided & $152 / 276(55.1)$ & $30 / 73(41.1)$ & $53 / 97(54.6)$ & $28(68.3)$ & $13(54.2)$ & $38(29.5)$ & $56(51.9)$ & 128/271 (47.2) & $3 / 68(4.4)$ & $92(55.1)$ & $12 / 24(50.0)$ & $605 / 1278(47.3)$ \\
\hline \multicolumn{13}{|l|}{$\begin{array}{l}\text { Interest in structured } \\
\text { research training }\end{array}$} \\
\hline - Yes & $75(26.7)$ & $25 / 80(31.3)$ & $40(40.8)$ & 13/39 (33.3) & $13(54.2)$ & $55(42.6)$ & $18 / 107(16.8)$ & $95 / 274(34.7)$ & $25 / 112(22.3)$ & $27(16.2)$ & $7 / 25(28.0)$ & 393/1336 (29.4) \\
\hline & $121(43.1)$ & $31 / 80(38.8)$ & $39(39.8)$ & 24/39 (61.5) & $8(33.3)$ & $55(42.6)$ & 69/107 (64.5) & 147/274 (53.6) & 63/112 (56.3) & $98(58.7)$ & $15 / 25(60.0)$ & 670/1336 (50.1) \\
\hline \multicolumn{13}{|l|}{$\begin{array}{l}\text { Interest to learn more } \\
\text { about... }\end{array}$} \\
\hline - Biostatistics only & 28/280 (10.0) & $6 / 79(7.6)$ & $1(1.0)$ & $3(7.3)$ & $0(0.0)$ & $5(3.9)$ & $10(9.3)$ & 24/279 (8.6) & $11 / 110(10.0)$ & 14/165 (8.5) & $2(7.7)$ & 104/1339 (7.8) \\
\hline - Research Ethics only & $37 / 280(13.2)$ & $5 / 79(6.3)$ & $35(35.7)$ & $18(43.9)$ & $4(16.7)$ & $23(17.8)$ & $25(23.1)$ & $34 / 279$ (12.2) & $17 / 100(15.5)$ & 18/165 (10.9) & $2(7.7)$ & 218/1339 (16.3) \\
\hline $\begin{array}{l}\text { - Both Biostatistics and } \\
\text { Research Ethics }\end{array}$ & $188 / 280(67.1)$ & $61 / 79(77.2)$ & $52(53.1)$ & $20(48.8)$ & $19(79.2)$ & $91(70.5)$ & $59(54.6)$ & 198/279 (71.0) & $77 / 110(70.0)$ & $120 / 165(72.7)$ & $21(80.8)$ & $906 / 1339(67.7)$ \\
\hline
\end{tabular}

NUS = National University of Singapore (includes students from both Yong Loo Lin School of Medicine and from Duke-NUS Graduate Medical School), Duke = Duke University, PUC = Pontificia Universidad Catolica de Chile, $B G U=$ Ben-Gurion University, UEM = Universidade Estadual De Maringa, UFMG = Federal University of Minas Gerais, NTNU = Norwegian University of Science and Technology, TU = Trisakti University, FCSU = Faculdade

* In cells where denominators are not included, all responders answered the question 
Table 3 presents the proportion of study participants who were confident in various aspects of biomedical research. For each of the named tasks, there was a remarkable balance between the students who indicated they were confident in carrying out the task and those who indicated they were not (i.e. many of the overall percentages were not too far from 50\%). An exception was the question about 'applying ethical principles', to which $70.4 \%$ of all the students answered that they were confident in doing so. Also of interest (not shown in Tables) was that $56.6 \%$ of the students felt that it is "easy to manipulate statistics to support results desired by investigators" while $95.4 \%$ felt that "to be an intelligent reader of the biomedical literature, it is necessary to know something about statistics".

We also investigated whether there were gender differences in terms of inclination towards a research career and other related questions (Table 4). While females were more likely to report that the quality of research had been important in their choice of medical school, more males were interested in pursuing a research project outside of the official curriculum and in a research career after graduation (marginally not statistically significant). Males were more interested in learning about biostatistics alone than females, while the converse was true for learning about research ethics.

The results outlined in Table 5 suggest that students with prior research experience were more likely to have an interest in a research career after graduation and in spending more time on research. However, they were less likely to be interested in pursing a research oriented Master or PhD after graduation.

\section{Discussion}

There is an increasing emphasis in many countries on training 'clinician scientists' and 'clinician investigators'. A sufficient critical mass of such individuals is crucial for the success of any biomedical research programme. It is therefore essential to understand the background and inclination of medical students towards research careers.

There are many factors that can influence the decision to pursue a research career. Among these are completing a graduate research degree along with a medical degree, having a desire to teach, the presence and influence of a role model, curiosity to discover the unknown, enjoyment of problem solving, having a high level of independence and a desire to help others indirectly through research (McGee \& Keller, 2007, Reynolds, 2008, Straus et al., 2006).

We investigated the inclination of medical students from 11 universities in different parts of the world towards careers in biomedical research. We also assessed students' confidence in biomedical research methodology and their ability to interpret and understand medical literature.

Although such studies have been done before, this study is one of the few to investigate the inclination of medical students towards careers in research, across different medical schools worldwide. This allows for larger numbers (both in terms of the number of students and the number of medical schools involved) and also a better representation and diversity of students, from a range of different cultures and medical school systems. A study by Burzeri et al (2005) was also international in nature, and indeed had a larger sample size than our study. However, it was limited to just Southeast European countries and the questions asked were less extensive and comprehensive compared to ours.

Although there was some variation among the schools, it is of concern that in all schools, less than a third of the first year students expressed an interest in pursuing a research career, with the overall results of our study suggesting that only about a quarter of students in their first year of medical school are inclined towards a career in research.

The emphasis of the study was not primarily to compare and contrast the different schools, but to obtain an overall picture of students' perception of research and research careers. Hence, no formal statistical tests/comparisons were made to compare the results between different individual schools.

Nevertheless there were some interesting features in the results observed in particular schools. For example, Trisakti University, although not a traditionally research-intensive university in terms of research output, had the highest proportion of students who felt that quality of research was important in their choice of medical school. Also these students seemed generally more confident in the aspects of undertaking research (Table 3) compared particularly to the other undergraduate medical schools. 
Table 3: Proportion of study participants confident in various aspects of biomedical research

\begin{tabular}{|c|c|c|c|c|c|c|c|c|c|c|c|c|}
\hline Confident in & $\begin{array}{c}\text { NUS } \\
\text { N=281* } \\
\mathrm{n}(\%)\end{array}$ & $\begin{array}{l}\text { Duke } \\
\mathrm{N}=2^{*} \\
\mathrm{n}(\%)\end{array}$ & $\begin{array}{l}\mathrm{PUC} \\
\mathrm{N}=\mathrm{g}^{*} \\
\mathrm{n}(\%)\end{array}$ & $\begin{array}{c}\mathrm{BGU} \\
\mathrm{N}=41^{\star} \\
\mathrm{n}(\%)\end{array}$ & $\begin{array}{c}\text { UEM } \\
\text { N=24 } \\
\mathrm{n}(\%)\end{array}$ & $\begin{array}{c}\text { University } \\
\text { UFMG } \\
\mathrm{N}=129^{\star} \\
\mathrm{n}(\%)\end{array}$ & $\begin{array}{c}\text { NTNU } \\
\mathrm{N}=108^{\star} \\
\mathrm{n}(\%)\end{array}$ & $\begin{array}{c}\mathrm{TU} \\
\mathrm{N}=280^{\star} \\
\mathrm{n}(\%)\end{array}$ & $\begin{array}{c}\text { FCSU } \\
\mathrm{N}=118^{*} \\
\mathrm{n}(\%)\end{array}$ & $\begin{array}{c}\mathrm{JCU} \\
\mathrm{N}=167^{\star} \\
\mathrm{n}(\%)\end{array}$ & $\begin{array}{c}\mathrm{UCT} \\
\mathrm{N}=2^{*} \\
\mathrm{n}(\%)\end{array}$ & $\begin{array}{l}\text { Overall } \\
\mathrm{n}(\%)\end{array}$ \\
\hline Interpreting the $\mathrm{P}$ value for a given result & $169(60.1)$ & $53 / 80(66.3)$ & $47(48.0)$ & $13(31.7)$ & $6(25.0)$ & $44(34.1)$ & 40/107 (37.4) & $132 / 237(55.7)$ & $55 / 99(55.6)$ & $51(30.5)$ & $8(30.8)$ & $618 / 1289(47.9)$ \\
\hline $\begin{array}{l}\text { Interpreting implications to clinical practice } \\
\text { for a given result from statistical analysis }\end{array}$ & $143(50.9)$ & $46 / 80(57.5)$ & $51 / 97(52.6)$ & $10(24.4)$ & $7 / 23(30.4)$ & $54 / 127(42.5)$ & $31(28.7)$ & 170/250 (68.0) & $65 / 109(59.6)$ & $65(38.9)$ & $18(69.2)$ & $660 / 1309(50.4$ \\
\hline $\begin{array}{l}\text { Assessing if correct statistical procedure was } \\
\text { used to answer a research question }\end{array}$ & $72(25.6)$ & $25 / 80(31.3)$ & $44 / 97(45.4)$ & $9(22.0)$ & $4(16.7)$ & $46(35.7)$ & 23/107 (21.5) & $188 / 249(75.5)$ & $62 / 104(59.6)$ & $64(38.3)$ & $10(38.5)$ & $547 / 1305(41.9)$ \\
\hline $\begin{array}{l}\text { Identifying factors that influence the } \\
\text { adequacy of a study's sample size }\end{array}$ & $149(53.0)$ & $40 / 80(50.0)$ & $77 / 97(79.4)$ & $21(51.2)$ & $5(20.8)$ & $56(43.4)$ & $30(27.8)$ & 188/242 (77.7) & $71 / 107(66.4)$ & $106(63.5)$ & $12 / 25(48.0)$ & 755/1301 (58.0) \\
\hline Applying ethical principles & 231/280 (82.5) & $56(68.3)$ & $48(49.0)$ & $30(73.2)$ & $6(25.0)$ & $61 / 117(52.1)$ & $57(52.8)$ & $211 / 262(80.5)$ & $92 / 112(82.1)$ & $119(71.3)$ & $16(61.5)$ & 927/1317 (70.4) \\
\hline $\begin{array}{l}\text { Criteria to justify authorship in research } \\
\text { journal publications }\end{array}$ & $79(28.1)$ & $35(42.7)$ & $22 / 97(22.7)$ & $14(34.1)$ & $5(20.8)$ & $37(28.7)$ & 9/107(8.4) & $167 / 253(66.0)$ & $54 / 106(50.9)$ & $53(31.7)$ & $5(19.2)$ & $480 / 1313(36.6)$ \\
\hline $\begin{array}{l}\text { Awareness of actions that constitute } \\
\text { publication misconduct }\end{array}$ & $120(42.7)$ & $36(43.9)$ & $48 / 97(49.5)$ & $23(56.1)$ & $4(16.7)$ & $53(41.1)$ & $22 / 107(20.6)$ & $170 / 249(68.3)$ & $48 / 104(46.2)$ & $60(35.9)$ & $8(30.8)$ & $592 / 1307$ (45.3) \\
\hline $\begin{array}{l}\text { In designing a study to answer a specific } \\
\text { hypothesis }\end{array}$ & $140(49.8)$ & $55(67.1)$ & 22/97 (22.7) & $13(31.7)$ & $3(12.5)$ & $22 / 117$ (18.8) & $32(29.6)$ & 228/277 (82.3) & 9/108 (8.3) & $113(67.7)$ & $19(73.1)$ & 656/1328 (49.4) \\
\hline $\begin{array}{l}\text { Understanding almost all of the study design } \\
\text { terms encountered in journal articles }\end{array}$ & $150(53.4)$ & 49 (59.8) & $36(36.7)$ & $11(26.8)$ & $9(37.5)$ & 49/127 (38.6) & $50(46.3)$ & 188/278 (67.6) & $20 / 105(19.0)$ & $\begin{array}{c}118 / 166 \\
(71.1)\end{array}$ & $15(57.7)$ & $695 / 1336(52.0)$ \\
\hline $\begin{array}{l}\text { Stating advantages and disadvantages of } \\
\text { each study design }\end{array}$ & 117 (41.6) & $42(51.2)$ & $16(16.3)$ & $14(34.1)$ & $7(29.2)$ & $38(29.5)$ & $36(33.3)$ & $211 / 273(77.3)$ & $36 / 106$ (34.0) & 90/165 (54.5) & $16(61.5)$ & 623/1333 (46.7) \\
\hline $\begin{array}{l}\text { Identifying ways of reducing bias when } \\
\text { designing studies }\end{array}$ & $158(56.2)$ & $48(58.5)$ & $44(44.9)$ & $7(17.1)$ & $3(12.5)$ & $26(20.2)$ & $28(25.9)$ & 194/271 (71.6) & $30 / 104(28.8)$ & $\begin{array}{c}129 / 165 \\
(78.2)\end{array}$ & $16 / 25(64.0)$ & 683/1328 (51.4) \\
\hline
\end{tabular}

NUS = National University of Singapore (includes students from both Yong Loo Lin School of Medicine and from Duke-NUS Graduate Medical School), Duke = Duke University, PUC = Pontificia Universidad Catolica de Chile, BGU = BenGurion University, UEM = Universidade Estadual De Maringa, UFMG = Federal University of Minas Gerais, NTNU = Norwegian University of Science and Technology, TU = Trisakti University, FCSU = Faculdade de Ciencias da Saúde,

* In cells where decra Ininators ar no Jan 
Table 4: Gender differences in research interest, and research inclination after graduation of study participants

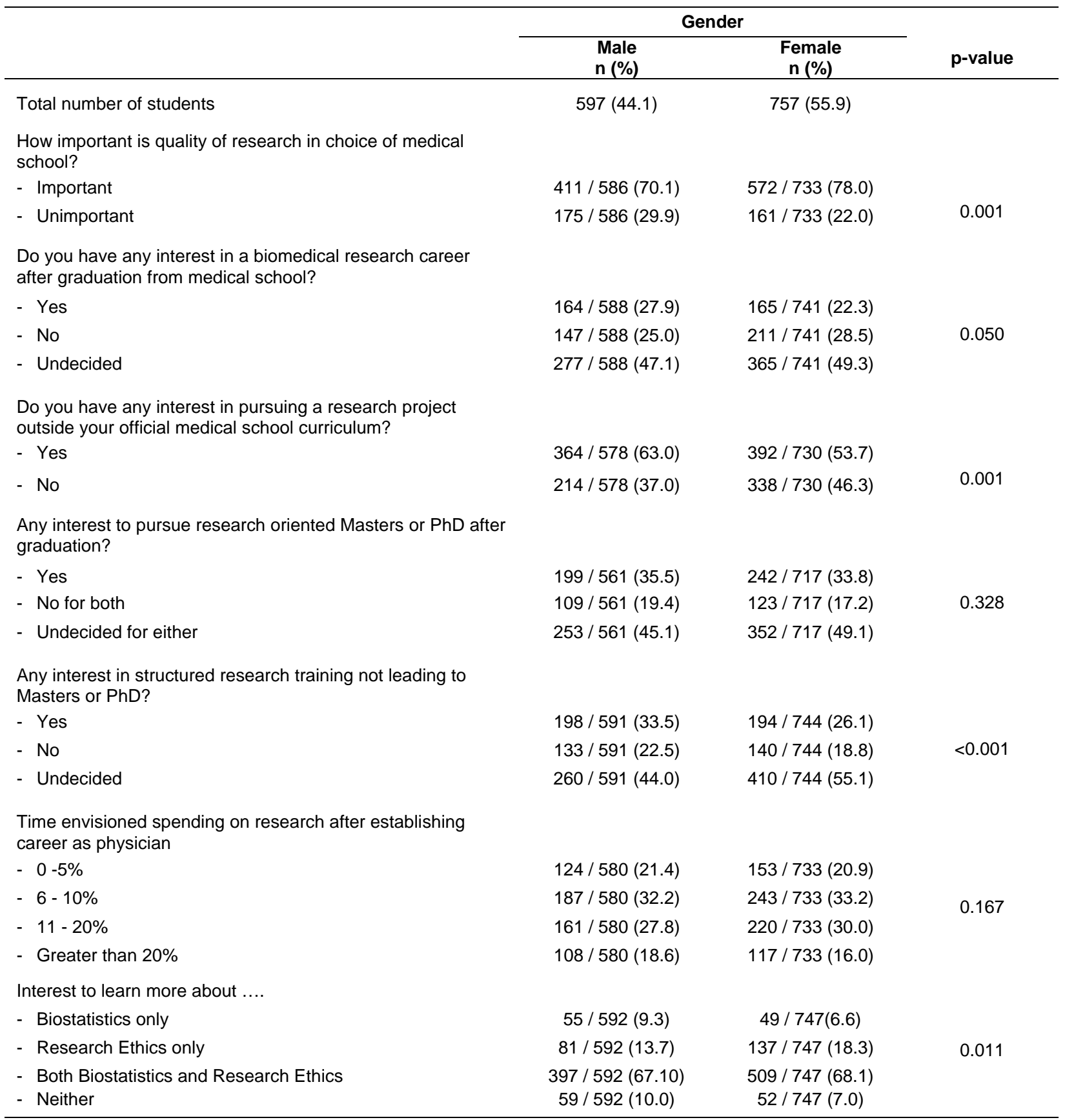


Table 5: Research background differences in research interest, and research inclination after graduation of study participants

\begin{tabular}{|c|c|c|c|}
\hline & \multicolumn{2}{|c|}{ Done any research before? } & \multirow[b]{2}{*}{$p$-value } \\
\hline & $\begin{array}{l}\text { Yes } \\
\text { n (\%) }\end{array}$ & $\begin{array}{c}\text { No } \\
\text { n (\%) }\end{array}$ & \\
\hline Total number of students & $405(30.3)$ & $931(69.7)$ & \\
\hline \multicolumn{4}{|c|}{$\begin{array}{l}\text { How important is quality of research in choice of medical } \\
\text { school? }\end{array}$} \\
\hline - Important & 311 / 396 (78.5) & $661 / 909$ (72.7) & \multirow{2}{*}{0.027} \\
\hline - Unimportant & 85 / 396 (21.5) & $248 / 909$ (27.3) & \\
\hline \multicolumn{4}{|c|}{$\begin{array}{l}\text { Do you have any interest in a biomedical research career } \\
\text { after graduation from medical school? }\end{array}$} \\
\hline - Yes & 123 / 401 (30.7) & 203 / 914 (22.2) & \multirow{3}{*}{0.002} \\
\hline - No & $90 / 401(22.4)$ & $260 / 914(28.4)$ & \\
\hline - Undecided & 188 / 401 (46.9) & 451 / $914(49.3)$ & \\
\hline \multicolumn{4}{|c|}{$\begin{array}{l}\text { Do you have any interest in pursuing a research project } \\
\text { outside your official medical school curriculum? }\end{array}$} \\
\hline - Yes & 233 / $392(59.4)$ & 514 / 899 (57.2) & \multirow{2}{*}{0.462} \\
\hline - No & 159 / $392(40.6)$ & 385 / 899 (42.8) & \\
\hline \multicolumn{4}{|c|}{$\begin{array}{l}\text { Any interest to pursue research oriented Masters or } \mathrm{PhD} \\
\text { after graduation? }\end{array}$} \\
\hline - Yes & $113 / 384(29.4)$ & $323 / 881(36.7)$ & \multirow{3}{*}{0.018} \\
\hline - No for both & $83 / 384$ (21.6) & $146 / 881(16.6)$ & \\
\hline - Undecided for either & 188 / $384(49.0)$ & 412 / 881 (46.8) & \\
\hline \multicolumn{4}{|c|}{$\begin{array}{l}\text { Any interest in structured research training not leading to } \\
\text { Masters or PhD? }\end{array}$} \\
\hline - Yes & 132 / 398 (33.2) & $256 / 920(27.8)$ & \multirow{3}{*}{0.094} \\
\hline - No & 83 / 398 (20.9) & $186 / 920(20.2)$ & \\
\hline - Undecided & 183 / 398 (46.0) & 478 / $920(52.0)$ & \\
\hline \multicolumn{4}{|c|}{$\begin{array}{l}\text { Time envisioned spending on research after establishing } \\
\text { career as physician }\end{array}$} \\
\hline$-0-5 \%$ & 66 / $392(16.8)$ & 207 / 904 (22.9) & \multirow{4}{*}{0.001} \\
\hline$-6-10 \%$ & 116 / 392 (29.6) & $310 / 904$ (34.3) & \\
\hline$-11-20 \%$ & 128 / $392(32.7)$ & 247 / 904 (27.3) & \\
\hline - Greater than $20 \%$ & 82 / 392 (20.9) & $140 / 904(15.5)$ & \\
\hline \multicolumn{4}{|l|}{ Interest to learn more about. } \\
\hline - Biostatistics only & $35 / 400$ (8.8) & $66 / 922(7.2)$ & \multirow{4}{*}{0.044} \\
\hline - Research Ethics only & 48 / 400 (12.0) & 166 / $922(18.0)$ & \\
\hline - Both Biostatistics and Research Ethics & $285 / 400(71.3)$ & $613 / 922(66.5)$ & \\
\hline - Neither & 32 / $400(8.0)$ & 77 / $922(8.4)$ & \\
\hline
\end{tabular}


The survey of these first year medical students represents the first phase of the overall project. It sets the foundation for the second phase, which is to follow up on the same students, at the end of their study in medical school, to assess any changes in inclination towards research careers and to see how this may be affected by the curriculum and format of teaching in each school. This is along the lines of the study by Gat and colleagues (2007), although their focus was specifically on residency in psychiatry.

As already indicated, one limitation of the study is the difficulty in comparing students from the different medical schools due to the large number of possible confounding factors, especially details about the different medical school curricula and learning 'milieus', most of which are not captured in the survey.

Other limitations include students who completed the questionnaires in languages other than English may have interpreted the questions slightly differently. Even for those who responded in English, there may be subtle differences between students who use English as their first language and students who use English as a foreign language. Likewise, there may be cultural differences that could affect their responses. However, it should be noted that we are studying perceptions, rather than actual knowledge. No formal sample size calculation was carried out as the intention was to try and recruit all first year medical students in each of the twelve medical schools involved. Likewise we had sought to include as many medical schools as we could in the collaboration, in order to maximise the number of students recruited.

\section{Conclusion}

Our study concluded that most students in their first year of medical school are not inclined towards a career in research. This finding applies internationally, across the different countries and medical school systems that were surveyed. Thus, the focus is on medical schools to help transform the perception and attitudes of their students during the course of their medical school training, so that a greater proportion will be interested in and ultimately choose research careers. This is particularly true for medical schools for which the training of graduates inclined towards careers in research is a priority. These schools may also want to refine their student selection or admission process to ensure that they accept students with a stronger aptitude and interest towards research careers.

\section{Conflicts of interest}

The author(s) declare that they have no conflicts of interest.

\section{Acknowledgements}

The authors wish to thank the following for their assistance: Pessach Shvartzman and Sial (Ben Gurion University, Israel); Jatin Shah and Dimple Dayaram Rajgor (Duke-NUS Graduate Medical School, Singapore); Lauren Simpson and Rebecca Brouwer (Duke University Medical School, USA); André Ricardo Masenssini (Federal University of Minas Gerais, Brazil), Roberto Zonato Esteves, (State University of Maringa, Brazil); and Moise Muzigaba (University of Western Cape, South Africa). This work was supported by the Duke-NUS Signature Research Program funded by the Agency for Science, Technology and Research, Singapore, and the Ministry of Health, Singapore.

\section{References}

Al-Nuaimi, Y., McGrouther, G. \& Bayat, A. (2008) Modernising medical careers and factors influencing career choices of medical students, Br J Hosp Med (Lond), 69, pp.163-166.

Andriole, D. A., Whelan, A. J. \& Jeffe, D. B. (2008) Characteristics and career intentions of the emerging MD/PhD workforce, JAMA, 300, pp.1165-1173.

Burazeri, G., Civljak, M., Ilakovac, V., Jankovic, S., Majica-Kovacevic, T., Nedera, O., Roshi, E., Sava, V., Simunovic, V., Marusic, A. \& Marusic, M. (2005) Survey of attitudes and knowledge about science in medical students in southeast Europe, BMJ, 331, pp.195-196.

Davis, W. K. \& Kelley, W. N. (1982) Factors influencing decisions to enter careers in clinical investigation. J Med Educ, 57, pp.275-281.

Evered, D. C., Anderson, J., Griggs, P. \& Wakeford, R. (1987) The correlates of research success, Br Med J (Clin Res Ed), 295, pp.241-246.

Gat, I., Abramowitz, M. Z., Bentov-Gofrit, D. \& Cohen, R. (2007) Changes in the attitudes of Israeli students at the Hebrew University Medical School toward residency in psychiatry: a cohort study, Isr J Psychiatry Relat Sci, 44, pp.194-203.

Houlden, R. L., Raja, J. B., Collier, C. P., Clark, A. F. \& Waugh, J. M. (2004) Medical students' perceptions of an undergraduate research elective, Med Teach, 26, pp.659-661. 
Huda, N. \& Yousuf, S. (2006) Career preference of final year medical students of Ziauddin Medical University, Educ Health (Abingdon), 19, pp.345-353.

Kassebaum, D. G., Szenas, P. L., Ruffin, A. L. \& Masters, D. R. (1995) The research career interests of graduating medical students, Acad Med, 70, pp.848-852.

Koenig, J. A. (1992) Comparison of medical school performances and career plans of students with broad and with science-focused premedical preparation, Acad Med, 67, pp.191-196.

Ley, T. J. \& Rosenberg, L. E. (2005) The physicianscientist career pipeline in 2005: build it, and they will come, JAMA, 294, pp.1343-1351.

Mcgee, R. \& Keller, J. L. (2007) Identifying future scientists: predicting persistence into research training, CBE Life Sci Educ, 6, pp.316-331.

Mcmanus, I. C., Richards, P. \& Winder, B. C. (1999) Intercalated degrees, learning styles, and career preferences: prospective longitudinal study of UK medical students, BMJ, 319, pp.542-546.
Neilson, E. G. (2003) The role of medical school admissions committees in the decline of physician-scientists, J Clin Invest, 111, 765767.

Nguyen-Van-Tam, J. S., Logan, R. F., Logan, S. A. \& Mindell, J. S. (2001) What happens to medical students who complete an honours year in public health and epidemiology? Med Educ, 35, pp.134-136.

Reynolds, H. Y. (2008) In choosing a research health career, mentoring is essential, Lung, 186, pp.1-6.

Rosenberg, L. (1999) Physician-scientists-endangered and essential, Science, pp.283, 331-332.

Solomon, S. S., Tom, S. C., Pichert, J., Wasserman, D. \& Powers, A. C. (2003) Impact of medical student research in the development of physician-scientists, J Investig Med, 51, pp.149-156.

Straus, S. E., Straus, C. \& Tzanetos, K. (2006) Career choice in academic medicine: systematic review, J Gen Intern Med, 21, pp.1222-1229. 